\title{
On the Measurement of Product Variety in Trade
}

\author{
by \\ Robert Feenstra \\ Department of Economics \\ University of California, Davis \\ and NBER \\ Hiau Looi Kee \\ Development Research Group - Trade \\ The World Bank
}

February 2003

Address for correspondence: Robert Feenstra, Dept. of Economics, University of California, Davis, CA 95616; Phone (530)752-7022; Fax (530)752-9382; rcfeenstra@ucdavis.edu

Prepared for the session "Dissecting International Trade: The Dimensions of National Market Penetration," American Economics Association, January 4, 2004. The authors thank the World Bank for providing research funding and support. The findings, interpretations, and conclusions expressed in this paper are entirely those of the authors, and do not necessarily represent the view of the World Bank, its Executive Directors, or the countries they represent. 


\section{Non-Technical Summary}

Product variety plays an important role in the theoretical work on monopolistic competition and trade, and recent empirical work has begun to quantify this for aggregate and disaggregate import demands. The objective of this paper is to discuss the measurement of product variety in trade, using a broad cross-section of advanced and developing countries and disaggregating across sectors. We calculate the export variety of countries in their sales to the United States, and relate the export variety indexes to country productivities. We confirm that countries with greater product variety in exports also have higher productivity. This may be due to their own development of, and access to, these products. 


\section{Introduction}

The theoretical work on monopolistic competition and trade has emphasized the important role of product variety, and recent empirical work has begun on quantify this. For example, David Hummels and Peter Klenow (2002) and Peter Schott (2004) have investigated the extent to which trade between countries consists of a common set of goods, or a larger set of goods from bigger countries, or different quality goods. These authors identify an important role for product variety and quality in explaining trade between countries. Christian Broda and David Weinstein (2003) have recently analyzed the product variety in U.S. imports, and find that increased variety contributes to a 1.2 percent per year fall in the "true" import price index. On the other side of the coin, a direct link between export variety and productivity have been found by Robert Feenstra et al (1999) for South Korea and Taiwan, and by Michael Funke and Ralf Ruhwedel (2001a, 2001b, 2002) for the OECD and the East Asian countries.

The objective of this paper is to discuss the measurement of product variety in trade, using a broad cross-section of advanced and developing countries and disaggregating across sectors. We calculate the export variety of countries in their sales to the United States. In a companion paper (Feenstra and Hiau Looi Kee, 2004), we also compute the total factor productivity across countries, using a translog GDP function. Here we make use of those results to illustrate the correlation between export variety and productivity.

\section{Measuring Product Variety across Countries}

Consider a world economy with many $c=1, \ldots, C$ countries, each of which produces many types of goods. For each period t, let the set of goods produced in country c be denoted by $\mathrm{I}_{\mathrm{t}}^{\mathrm{c}} \subset\{1,2,3, \ldots$.$\} . For \mathrm{i} \in \mathrm{I}_{\mathrm{t}}^{\mathrm{c}}$ the quantity of good $\mathrm{i}$ is $\mathrm{q}_{\mathrm{it}}^{\mathrm{c}}>0$, and the vector of each type of good 
produced in country $\mathrm{c}$ in period $\mathrm{t}$ is denoted by $\mathrm{q}_{\mathrm{t}}^{\mathrm{c}}>0$. The aggregate output of each country $\mathrm{c}$, $\mathrm{Q}_{\mathrm{t}}^{\mathrm{c}}$, is characterized by a CES function of the outputs of each good in the country:

$$
Q_{t}^{c}=f\left(q_{t}^{c}, I_{t}^{c}\right)=\left(\sum_{i \in I_{t}^{c}} a_{i}\left(q_{i t}^{c}\right)^{(\sigma-1) / \sigma}\right)^{\sigma /(\sigma-1)}, a_{n}>0, c=1, \ldots, C,
$$

where the elasticity of substitution between goods is $\sigma$. We assume that total output obtained from the economy is constrained by the transformation curve:

$$
F\left[f\left(q_{t}^{c}, I_{t}^{c}\right), V_{t}^{c}\right]=0
$$

where $V_{t}^{c}=\left(v_{1 t}^{c}, v_{2 t}^{c}, \ldots, v_{M t}^{c}\right)>0$ is the endowment vector for country $\mathrm{c}$ in year $\mathrm{t}$.

For outputs we suppose that $-\infty<\sigma<0$ in (1), which means that the feasible varieties $\mathrm{q}_{\mathrm{it}}^{\mathrm{c}}$ in any country lie along a strictly concave transformation curve, satisfying $\mathrm{Q}_{\mathrm{t}}^{\mathrm{c}}=\overline{\mathrm{Q}}_{\mathrm{t}}^{\mathrm{c}}$. Given resources, $\sigma<0$ captures the production trade-off between different outputs according to the underlying rate of technical transformation. This is shown in Figure 1, where we draw the transformation frontier between two product varieties $\mathrm{q}_{1 \mathrm{t}}$ and $\mathrm{q}_{2 \mathrm{t}}$. As $\sigma$ rises toward zero, the transformation curve is more concave. For a given transformation curve and prices, an increase in the number of output varieties will raise revenue. For example, if only output variety 1 is available, then the economy would be producing at the corner A, with output revenue shown by the line AB. Then if variety 2 becomes available, the new equilibrium will be at point $\mathrm{C}$, with an increase in revenue. This illustrates the benefits of output variety. ${ }^{1}$

\footnotetext{
${ }^{1}$ For inputs we would instead use that $\sigma>1$ in (1), which is then the formula for a CES production function. For given output, the inputs would lie along a convex isoquant. If only one input is available, then costs would be minimized at a corner, but with two inputs costs would be minimized at an interior point, with a fall in costs. This illustrates the benefits of input variety. We use the output case to illustrate the effects of export variety, whereas the input case would apply to import variety (as in Feenstra, 1994 and Broda and Weinstein, 2003).
} 
Consider maximizing the value of output, as in Figure 1. Under the assumption of perfect competition, and given equation (1), the value of output obtained in each country will be $\mathrm{P}_{\mathrm{t}}^{\mathrm{c}} \mathrm{Q}_{\mathrm{t}}^{\mathrm{c}}$, where $\mathrm{P}_{\mathrm{t}}^{\mathrm{c}}$ is a CES function of the prices of all product varieties produced in the country:

$$
P_{t}^{c} \equiv c\left(p_{t}^{c}, I_{t}^{c}\right)=\left(\sum_{i \in I_{t}^{c}} b_{i}\left(p_{i t}^{c}\right)^{1-\sigma}\right)^{1 /(1-\sigma)}, b_{i}=a_{i}^{\sigma}>0, c=1, \ldots, C
$$

and $\mathrm{p}_{\mathrm{t}}^{\mathrm{c}}>0$ is the domestic price vector for each country.

The right-hand side of expression (3) is a CES cost function, with potentially differing sets of product varieties across countries and over time. These cannot be evaluated without knowledge of the parameters $b_{i}$. But a result from index number theory is that the ratio of cost functions can be evaluated, using data on prices and quantities in the two periods or two countries. Feenstra (1994) shows how this result applies even when the number of goods is changing. In particular, the ratio of the CES cost functions over two countries a and $b$ equals the product of a price index of goods that are common, $\mathrm{I}_{\mathrm{t}} \equiv\left(\mathrm{I}_{\mathrm{t}}^{\mathrm{a}} \cap \mathrm{I}_{\mathrm{t}}^{\mathrm{b}}\right) \neq \varnothing$, multiplied by terms reflecting the revenue share of "unique" goods:

$$
\frac{P_{t}^{a}}{P_{t}^{b}}=\prod_{i \in I_{t}}\left(\frac{p_{i t}^{a}}{p_{i t}^{b}}\right)^{w_{i t}\left(I_{t}\right)}\left(\frac{\lambda_{t}^{a}\left(I_{t}\right)}{\lambda_{t}^{b}\left(I_{t}\right)}\right)^{1 /(\sigma-1)} \quad, a, b=1, \ldots, C
$$

where the weights $\mathrm{w}_{\mathrm{it}}\left(\mathrm{I}_{\mathrm{t}}\right)$ are constructed from the revenue shares in the two countries:

$$
\begin{aligned}
& \mathrm{w}_{\mathrm{it}}\left(\mathrm{I}_{\mathrm{t}}\right) \equiv\left(\frac{\mathrm{s}_{\mathrm{it}}^{\mathrm{a}}\left(\mathrm{I}_{\mathrm{t}}\right)-\mathrm{s}_{\mathrm{it}}^{\mathrm{b}}\left(\mathrm{I}_{\mathrm{t}}\right)}{\ln \mathrm{s}_{\mathrm{it}}^{\mathrm{a}}\left(\mathrm{I}_{\mathrm{t}}\right)-\ln \mathrm{s}_{\mathrm{it}}^{\mathrm{b}}\left(\mathrm{I}_{\mathrm{t}}\right)}\right) / \sum_{\mathrm{i} \in \mathrm{I}_{\mathrm{t}}}\left(\frac{\mathrm{s}_{\mathrm{it}}^{\mathrm{a}}\left(\mathrm{I}_{\mathrm{t}}\right)-\mathrm{s}_{\mathrm{it}}^{\mathrm{b}}\left(\mathrm{I}_{\mathrm{t}}\right)}{\ln \mathrm{s}_{\mathrm{it}}^{\mathrm{a}}\left(\mathrm{I}_{\mathrm{t}}\right)-\ln \mathrm{s}_{\mathrm{it}}^{\mathrm{b}}\left(\mathrm{I}_{\mathrm{t}}\right)}\right), \\
& \mathrm{s}_{\mathrm{it}}^{\mathrm{c}}\left(\mathrm{I}_{\mathrm{t}}\right) \equiv \mathrm{p}_{\mathrm{it}}^{\mathrm{c}} \mathrm{q}_{\mathrm{it}}^{\mathrm{c}} / \sum_{\mathrm{i} \in \mathrm{I}_{\mathrm{t}}} \mathrm{p}_{\mathrm{it}}^{\mathrm{c}} \mathrm{q}_{\mathrm{it}}^{\mathrm{c}}, \text { for } \mathrm{c}=\mathrm{a}, \mathrm{b},
\end{aligned}
$$

and the terms $\lambda_{t}^{a}\left(I_{t}\right)$ and $\lambda_{t}^{b}\left(I_{t}\right)$ are: 


$$
\lambda_{t}^{c}\left(I_{t}\right)=\frac{\sum_{i \in I_{t}} p_{i t}^{c} q_{i t}^{c}}{\sum_{i \in I_{t}^{c}} p_{i t}^{c} q_{i t}^{c}}=1-\frac{\sum_{i \in I_{t}^{c}, i \notin I_{t}} p_{i t}^{c} q_{i t}^{c}}{\sum_{i \in I_{t}^{c}} p_{i t}^{c} q_{i t}^{c}}, \text { for } c=a, b .
$$

Notice that the output shares in (6), for each country, are measured relative to the common set of goods I. Then the weights in (5) are the logarithmic mean of the shares $\mathrm{s}_{\mathrm{it}}^{\mathrm{a}}\left(\mathrm{I}_{\mathrm{t}}\right)$ and $\mathrm{s}_{\mathrm{it}}^{\mathrm{b}}\left(\mathrm{I}_{\mathrm{t}}\right)$, and sum to unity over the set of goods $i \in \mathrm{I}_{\mathrm{t}}{ }^{2}$

The first term on the right of (4) is the price index due to Kazuo Sato (1976) and Y.O. Vartia (1976), which is simply a weighted average of the price ratios, using the values $w_{i t}\left(I_{t}\right)$ as weights. What is new about equation (4) is the second term on the right, which reflect changes in product variety. If country $\mathrm{c}$ in period thas new, unique outputs (not in the common set $\mathrm{I}_{\mathrm{t}}$ ), we will have $\lambda_{t}^{c}<1$. From (4), when $\sigma<0$ this will raise the price index of outputs, $\mathrm{P}_{t}^{\mathrm{a}} / \mathrm{P}_{\mathrm{t}}^{\mathrm{b}}$. In other words, the introduction of new output varieties will act in the same way as an increase in prices in a sector: it will draw resources toward that sector. ${ }^{3}$

In practice, we measure the ratio $\lambda_{t}^{a} / \lambda_{t}^{b}$ using exports of 34 countries to the United States. While it would be preferable to use their worldwide exports, our data for the U.S. are more disaggregated, and allows for a finer measurement of "unique" products sold by one country and not another. Specifically, for 1982-88 we use the 7-digit Tariff Schedule of the U.S. Annotated (TSUSA) classification of U.S. imports, and for 1989-97 we use the 10-digit Harmonized System (HS) classification of imports.

\footnotetext{
2 More precisely, the numerator of (5) is the logarithmic mean of the output shares of the two countries, and lies between these shares. The denominator of (5) is introduced so that the weights $\mathrm{w}_{\mathrm{it}}\left(\mathrm{I}_{\mathrm{t}}\right)$ sum to unity.

3 If instead we consider the case of input variety, then $\sigma>1$ in (4). Then the introduction of new inputs will lower their price index. Thus, new input varieties would have the same positive efficiency effect as would a drop in input prices.
} 
To measure the ratio $\lambda_{t}^{a} / \lambda_{t}^{b}$, we need to decide on a consistent "comparison country." For this purpose, we use the worldwide exports from all countries to the U.S. as the comparison. Denote this comparison country by *, so that the set $I_{t}^{*}=\bigcup_{c=1}^{c} I_{t}^{c}$ is the complete set of varieties imported by the United States in year $t$, and $p_{i t}^{*} q_{i t}^{*}$ is the total value of imports for good $i$. Then comparing country $\mathrm{c}$ to country $*$ in year $\mathrm{t}$, it is immediate that the common set of goods exported is $I_{t}^{c} \cap I_{t}^{*}=I_{t}^{c}$, or simply the set of goods exported by country c. Therefore, from (7) we have that $\lambda_{t}^{\mathrm{c}}\left(\mathrm{I}_{\mathrm{t}}^{\mathrm{c}}\right)=1$, and:

$$
\lambda_{t}^{*}\left(I_{t}^{c}\right)=\frac{\sum_{i \in I_{t}^{c}} p_{i t}^{*} q_{i t}^{*}}{\sum_{i \in I_{t}^{*}} p_{i t}^{*} q_{i t}^{*}}=1-\frac{\sum_{i \in I_{t}^{*}, i \in I_{t}^{c}} p_{i t}^{*} q_{i t}^{*}}{\sum_{i \in I_{t}^{*}} p_{i t}^{*} q_{i t}^{*}} .
$$

Noting from (4) that product variety in country c relative to the comparison is measured as $\lambda_{t}^{c}\left(I_{t}^{c}\right) / \lambda_{t}^{*}\left(I_{t}^{c}\right)$, but this has a negative coefficient when $\sigma<0$, let us instead invert it and measure product variety of country c relative to the world by $\lambda_{t}^{*}\left(I_{t}^{c}\right) / \lambda_{t}^{c}\left(I_{t}^{c}\right)=\lambda_{t}^{*}\left(I_{t}^{c}\right)$, which enters (4) with a positive coefficient $1 /(1-\sigma)$. It is interpreted as the share of total U.S. imports from products that are exported by country $c$. Equivalently, it is one minus the share of total U.S. imports from products that are not exported by country $c$. Note that this measure depends on the set of exports by country c, $\mathrm{I}_{\mathrm{t}}^{\mathrm{c}}$, but not on its value of exports, except insofar as they affect the value of worldwide exports.

\section{Export Variety and Country Productivity}

Figure 2 presents a scatter plot of the export variety in 1991 for the sales of 34 countries to the United States, against their country productivities. Both variables are shown in deviation 
from their sample means in the figure. There is a clear positive relationship between the product variety of a country and its productivity, which is highlighted by the positive sloping regression line. Canada has the most product variety, and Canada produces nearly twice as much variety as the sample mean. In terms of the productivity differences, Canada is 7 percent higher than the sample mean. Japan has the highest productivity which is 12 percent higher than the sample mean. In terms of export variety, Japan produces 80 percent more export products than the sample mean. Other countries that have higher than sample productivity and export variety include South Korea, Singapore, and some other OECD countries such as France and Australia. These countries appear on the first quadrant. Countries that perform poorly in terms of the country productivity and export variety are in the third quadrant. They include Kenya, Greece, the Philippines, Turkey and Uruguay. For example, exporting industries in Uruguay produce less than half of the variety relative to the sample mean in 1991, and productivity is 10 percent less than the sample average. Similarly, Turkey produces 73 percent less export variety than the sample mean, and its productivity is 9 percent lower. We can also compare country pairs from the figure. For instance, in 1991, Singapore produces nearly 65 percent more export products than the Philippines, and the country productivity advantage of Singapore over the Philippines is about 12 percent. This is consistent with Kee (2002) where the growth of Singapore's major exporting industry is shown to be mainly driven by productivity.

We can also explore the movement of export variety and productivity within a country over time. Figure 3 compares Canada to the sample mean in terms of productivity, varietyinduced productivity differences, and the weighted-average export variety, from 1983 to $1997 .^{4}$ The two productivity series are presented in bars relative to the left-hand scale. The export

\footnotetext{
${ }^{4}$ The variety-induced productivity differences are that portion of total country productivities that can be explained by export variety; see Feenstra and Kee (2004).
} 
variety index is shown in line in the figure, measured relative to the vertical right hand scale. In 1983, Canada's productivity is 8.2 percent higher than the sample mean, while it produces 86 percent more exports products relative to the sample mean. In 1997, the productivity gap reduces to 6.7 percent while the export variety difference is about 61 percent. Thus over the years, we see a gradual decline of export variety in Canada, especially since the early 1990s, and it is reflected in the productivity series.

Figure 4 compares Japan to South Korea. Similar to the previous figure, the two productivity series are presented in bars relative to the left-hand scale. The product variety index is shown by the line in the figure, relative to the right-hand scale. The line series shows that, in 1982, Japan produced 53 percent more export variety than South Korea. The Japanese advantage over Korea deteriorates over time such that in 1995, Japan only produced 18 percent more variety than Korea. On the other hand, the first bar series shows that, over the same period of time, the underlying productivity advantage of Japan declines from 18 percent to less than 2 percent. Thus with Korea catching up in export variety, the underlying productivity gap between Korea and Japan is also narrowing.

In summary, Figure 2 clearly shows a cross-sectional correlation between export variety and country productivity, while Figures 3 and 4 show the same result over time. This illustrates that countries with greater product variety in exports also have higher productivity, which may be due to their own development of, and access to, these products. Of course, this logic can also work in reverse, whereby countries with higher productivity will export more varieties, as occurs in the model of Jonathan Eaton and Samuel Kortum (2002), for example. Regardless of the causation, the close link between export variety and productivity neatly confirms our theoretical expectation, and deserves to be explored further empirically. 


\section{References}

Broda, Christian and David Weinstein. "Globalization and the Gains from Variety." Federal Reserve Bank, New York and Columbia University, 2003.

Eaton, Jonathan and Samuel Kortum. "Technology, Geography and Trade." Econometrica, September 2002, 70(5), 1741-1780.

Feenstra, Robert C. "New Product Varieties and the Measurement of International Prices." American Economic Review, March 1994, 84(1), 157-177.

Feenstra, Robert C., Dorsati Madani, Tzu-Han Yang, and Chi Yuan Liang. "Testing Endogenous Growth in South Korea and Taiwan.” Journal of Development Economics, 1999, 60, 317 341.

Feenstra, Robert C. and Hiau Looi Kee. "Export Variety and Country Productivity." University of California, Davis and the World Bank, 2004.

Funke, Michael and Ralf Ruhwedel. "Product Variety and Economic Growth: Empirical Evidence from the OECD Countries." IMF Staff Papers, 2001a, 48(2), 225-242.

Funke, Michael and Ralf Ruhwedel. "Export Variety and Export Performance: Evidence from East Asia." Journal of Asian Economics, 2001b, 12, 493-505.

Funke, Michael and Ralf Ruhwedel. "Export Variety and Export Performance: Empirical Evidence for the OECD Countries." Weltwirtschaftliche Archiv, 2002, 138(1), 97-114.

Hummels, David and Peter Klenow. "The Variety and Quality of a Nation's Trade.” NBER paper 8712, 2002.

Kee, Hiau Looi. "Productivity versus Endowments: A Study of Singapore's Sectoral Growth." The World Bank, 2002.

Sato, Kazuo. "The Ideal Log-Change Index Number." Review of Economics and Statistics 58, May 1976, 223-228.

Schott, Peter. "Across-Product versus Within-Product Specialization in International Trade." Quarterly Journal of Economics, 2004, forthcoming.

Vartia, Y. O. "Ideal Log-Change Index Numbers.” Scandinavian Journal of Statistics, 1976, 3, 121-126. 


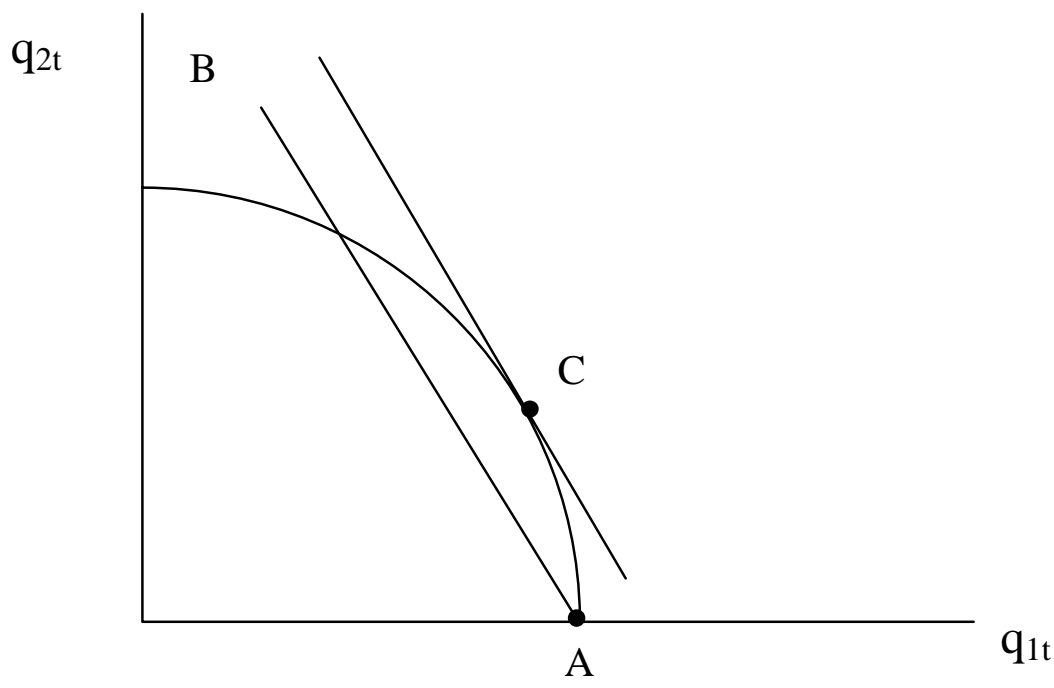

Figure 1: Output Varieties

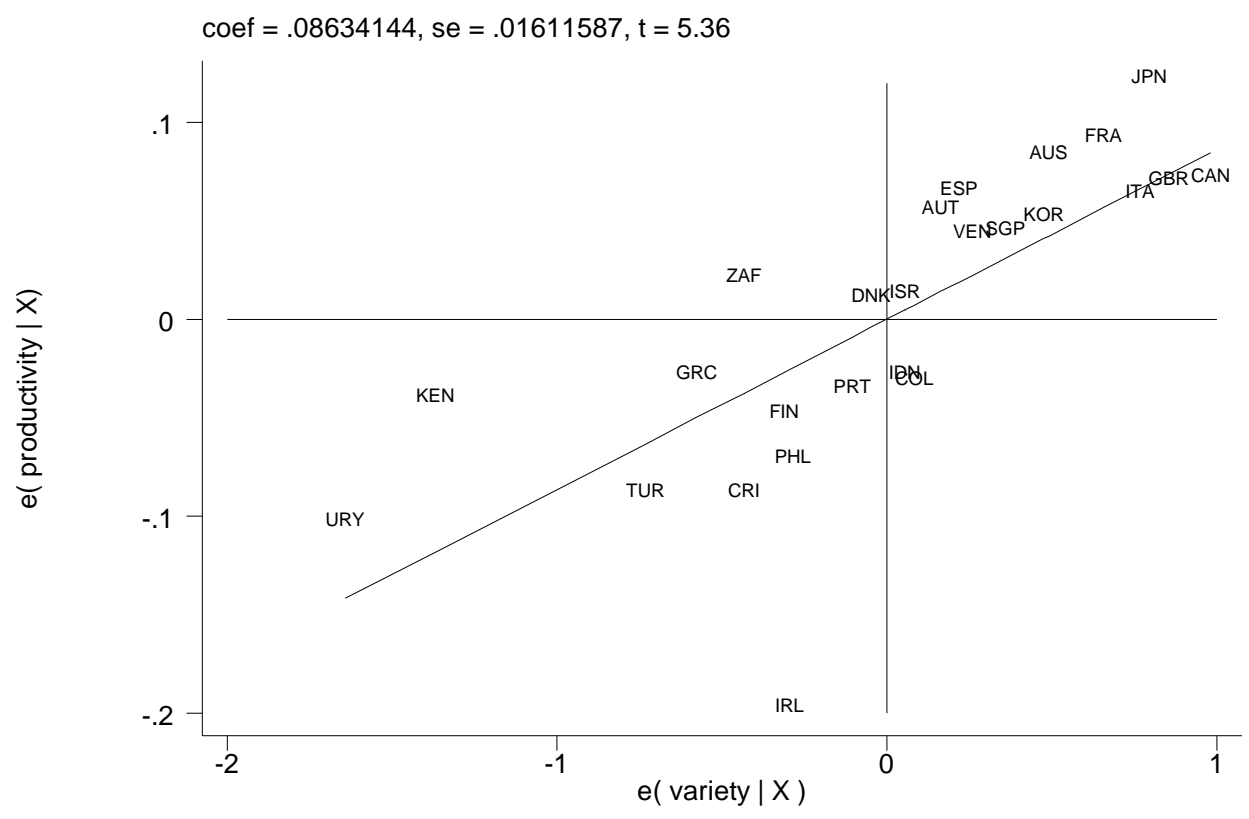

Figure 2: Productivity Differences without Country Fixed Effects versus Product Variety Differences, 1991 


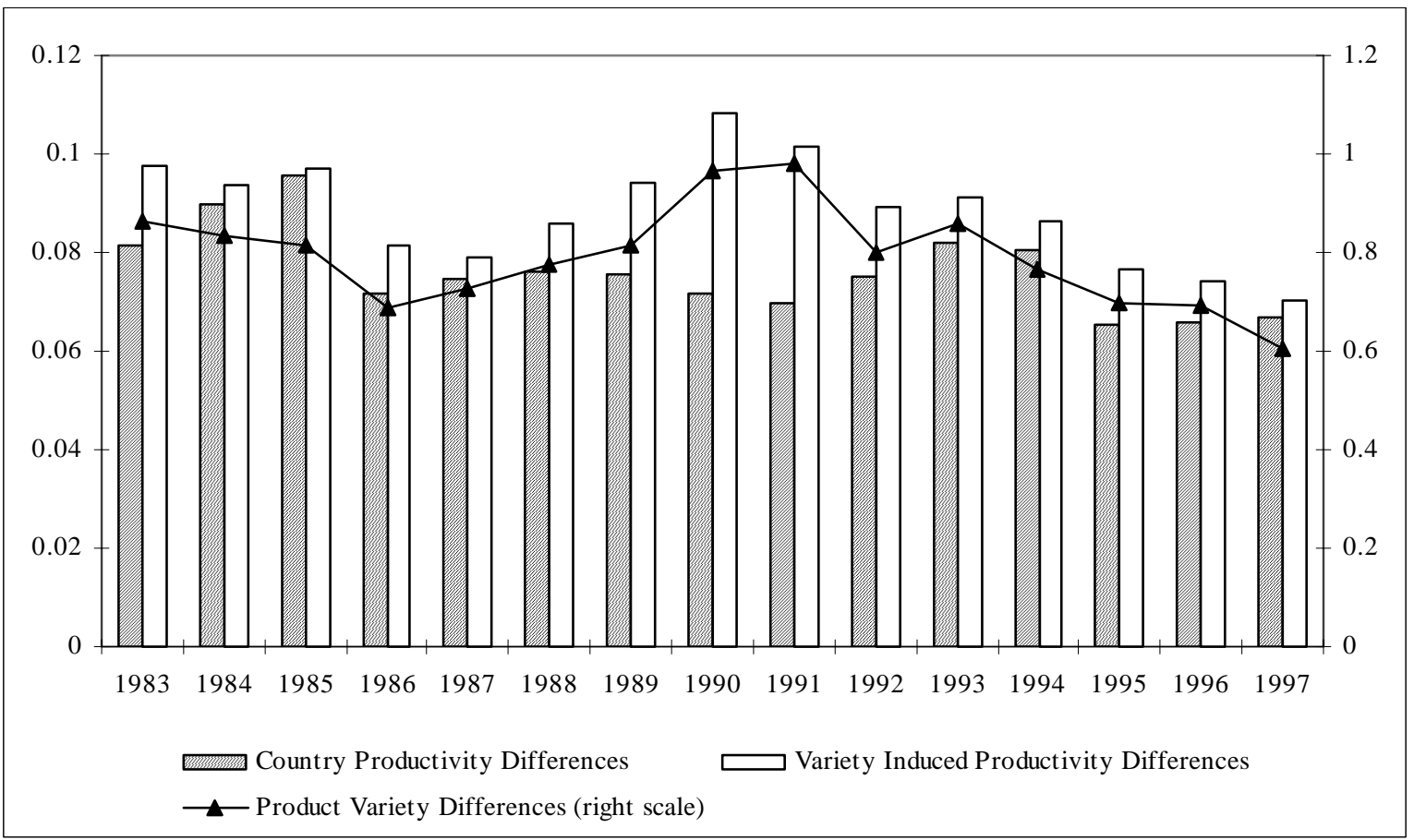

Figure 3: Canada Compared to Sample Mean

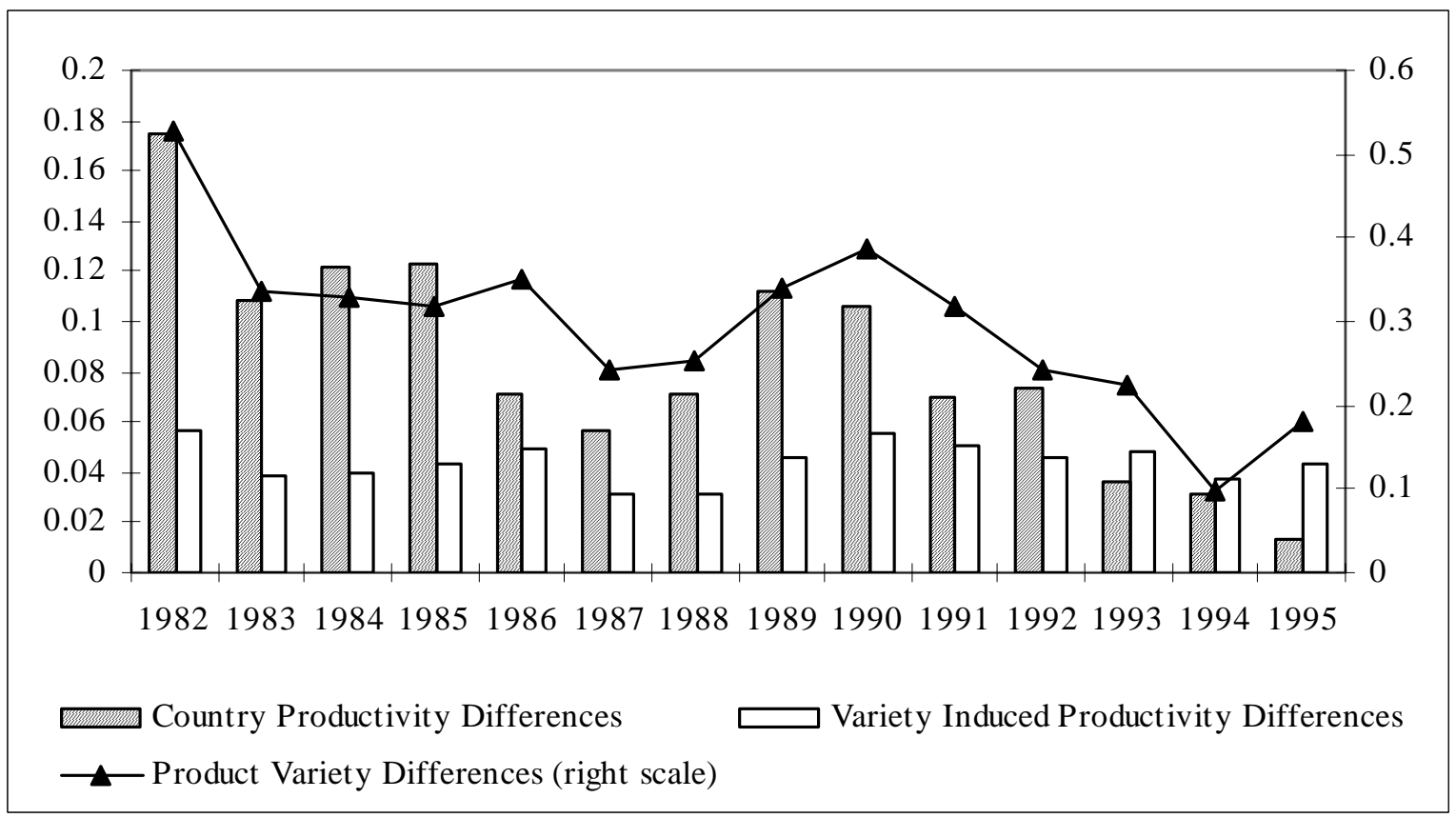

Figure 4: Japan Compared to South Korea 